\title{
Down-regulatory Influence of Methanol and Aqueous Root Extracts of Sphenocentrum jollyanum on Some Fertility Hormones and the Effect on Testicular Size of Wistar Albino Rats
}

\author{
S. I. Egba ${ }^{1^{*}}$, H. C. Omeoga ${ }^{1}$, C. E. Oriaku ${ }^{1}$, E. C. Jacob ${ }^{1}$, F. C. Nnabugwu ${ }^{1}$, \\ J. C. Lazarus ${ }^{1}$ and E. N. Echem ${ }^{1}$ \\ ${ }^{1}$ Department of Biochemistry, College of Natural and Applied Sciences, Michael Okpara University of \\ Agriculture, Umudike, Abia State, Nigeria.
}

Authors' contributions

This work was carried out in collaboration between all authors. Author SIE designed the study, carried out laboratory analysis and wrote the manuscript. Authors HCO and CEO took care of the animals, carried out statistical analysis and wrote first draft of the manuscript while authors ECJ, FCN, JCL and

ENE also catered for the animals, administered extracts and managed the literature searches. All authors read and approved the final manuscript.

Article Information

DOI: $10.9734 / A R R B / 2017 / 36598$

Editor(s):

(1) Yalemtsehay Mekonnen, College of Natural Sciences, Addis Ababa University, Ethiopia.

(2) George Perry, Dean and Professor of Biology, University of Texas at San Antonio, USA.

Reviewers:

(1) Dinithi Peiris, University of Sri Jayewardenepura, Sri Lanka.

(2) Divya S. Rajan, Kerala University, India.

Complete Peer review History: http://www.sciencedomain.org/review-history/21380

Original Research Article

Received $1^{\text {st }}$ September 2017

Accepted $27^{\text {th }}$ September 2017

Published $13^{\text {th }}$ October 2017

\begin{abstract}
Objective: The study is aimed at investigating the effects of oral administration of aqueous and methanol extract of the root of Sphenocentrum jollyanum on testicular size, testosterone, folliclestimulating hormone, luteinizing hormone and prolactin levels in male Wistar albino rats.

Methods: A total of 24 Wistar albino rats of equal sexes were randomly distributed into three groups having 4-rats each of both sexes. Group 1 served as the control and was administered distilled water ad libitum while groups 2 and 3 were administered $400 \mathrm{mg} / \mathrm{kg}$ body weight methanol and aqueous extracts respectively. Oral administration lasted for 14 days at the end of which animals were sacrificed and blood samples were collected from all the groups through ocular
\end{abstract}


puncture into plain sample bottles for hormonal assay. The serum level of progesterone, estradiol, testosterone, follicle stimulating hormone, luteinizing hormone and prolactin were determined using enzyme-linked immunosorbent assay (ELISA) technique. The testicular weight of the animals was equally determined.

Results: There was a non-significant $(p>0.05)$ variation in the mean testicular size of the treated and control rats, although the testicular size of the treated rats increased within the period when compared with the control group. Furthermore the administration of both aqueous and methanol root extracts of $S$. jollyanum caused non-significant $(p>0.05)$ decrease in estradiol concentration when compared to the control. The levels of progesterone, follicle stimulating hormone, luteinizing hormone and prolactin significantly $(p<0.05)$ decreased when compared to the control in the aqueous-treated group while the methanol extract-treated group showed a non-significant $(p>0.05)$ difference in the luteinizing hormone and prolactin levels while follicle stimulating hormone was significantly $(p<0.05)$ decreased. All comparisons were made against the control group. A significant $(p<0.05)$ decrease in testosterone concentration of the aqueous group and a nonsignificant $(p>0.05)$ decrease in the methanol extract group was seen in male rats. The result of follicle stimulating hormone level showed a significant $(p<0.05)$ decrease in both aqueous and methanol extracts treated groups while a non-significant $(p>0.05)$ reduction in luteinizing hormone was observed in both extract administered rats.

Conclusion: The results of this study showed that the aqueous and methanol root extracts of the S. jollyanum may possess anti-fertility properties in both sexes and can have some implications for fertility and contraception.

Keywords: Fertility; hormones; Sphenocentrum jollyanum; testicular size.

\section{INTRODUCTION}

Fertility is defined as the ability of an organism to reproduce itself by exchange of the gens from two individuals [1]. Hormones regulate the process of reproduction. Male reproduction is a complex process that is coordinated and controlled by male reproductive hormones. These include; testosterone, luteinizing hormone and follicle stimulating hormone Testes performs such intricate reproductive functions like spermatogenesis and sterodiogenesis leading to formation and maturation of spermatozoa. [2]. The anterior pituitary controls reproductive processes through the secretion of gonadotropins, luteinizing hormone (LH) and follicle stimulating hormone (FSH). The gonadotropins; $\mathrm{FSH}$ and $\mathrm{LH}$ directly control spermatogenesis and indirectly stimulate endogenous testosterone production. Testosterone is very useful in the completion of the spermatogenetic process as it enhances conversion of round spermatids to spermatozoa during spermatogenesis [3-5].

Plants have been shown to be good sources of numerous phytochemicals. They play indispensable roles in the management of different disease conditions [6]. They are known to possess medicinal properties. Large chunk of global population still rely on herbal preparations for management of different health conditions.
Most of these people reside in third world countries such as in Africa [7,8]. Many plants and their extracts have proved to have anti-fertility properties in folklores with no significant effect of toxicity $[9,10]$ one such plant is Sphenocentrum jollyanum.

S. jollyanum is widely used in the treatment of various human diseases. Its edible fruits [11] are used as an anti-fatigue snacks. In Nigeria, a decoction of the root is applied to manage diabetes and tropical ulcer $[12,13]$. The roots can be used in dental care, maintenance of smooth bowel movement, treatment of stomach ache and boosting of sexual drive [14]. It is usually prepared with addition of Piper guineense and most times mixed with lime juice for use as cough medicine. It has also been shown that virtually all parts of the plant are important ingredients for management of sickle cell disease [14]. Some applications include the use of its root hairs in combination with other anti-malarial plants as remedies against fever, body pains and rheumatism and the application of leafy twigs and fruits for their aphrodisiac activity $[15,16,17]$. The fruit can also be chewed and it has also been shown to have a role in the treatment of fibroids in traditional Nigerian medicine [18]. This work is aimed at investigating possible up/down regulatory effects of aqueous and methanolic root extracts of Sphenoncentrum jollyanum on some male and female reproductive hormones hormones in Wistar albino rats. 


\section{MATERIALS AND METHODS}

The roots of Sphenocentrum jollyanum pierre (family Menispermaceae) were harvested from Nssuka in Enugu State, Nigeria and identified at the Department of Plant Science and Biotechnology, Michael Okpara University of Agriculture, Umudike by Dr. Garuba Omosun. The roots were oven-dried.

\subsection{Preparation of Root Extract}

The roots were first chopped into small pieces and were then pulverized into coarse powder using a hammer-mill. 200 gram of the coarse powder plant root was soaked in $1000 \mathrm{ml}$ of methanol $(\mathrm{MeOH})$ and allowed to stand for a period of 48 hours under room temperature. It was further macerated and filtered first with muslin cloth and then, Whatman No 2 filter paper. The filtrate was then allowed to evaporate to dryness under controlled temperature $\left(60^{\circ} \mathrm{C}\right)$ using water bath. The yield was then analyzed and stored for the experiment. For aqueous (Aqu) extract, $20 \mathrm{~g}$ of the sample was soaked in $300 \mathrm{ml}$ of distilled water for 48 hours under room temperature. It was concomitantly macerated and filtered using muslin cloth and then filter paper. The filtrate was concentrated to half which was stored in the refrigerator and is hereafter referred to as extract.

\subsection{Experimental Animals and Grouping}

A total of 24 Wistar albino rats of equal sexes weighing 133-280 gram were purchased from the Department of Zoology and Environmental Biology, University of Nigeria, Nsukka. They were housed at the animal house unit of Biochemistry Department, Michael Okpara University of Agriculture, Umudike, Abia State, Nigeria. The animals were subsequently fed with commercial growers mash (Vital feed) and water ad libitum. After acclimatization which lasted for a period of two weeks, they were then randomly grouped thus:

Group 1: $400 \mathrm{mg} / \mathrm{kg}$ body weight, Methanol extract.

Group 2: $400 \mathrm{mg} / \mathrm{kg}$ body weight, Aqueous extract.

Group 3: Feed and clean drinking water (control).

The above groupings and administration was done for both sexes and lasted for a period of 14 days and were then gently sacrificed.

\subsection{Hormonal Assay}

The enzyme-linked immunosorbent assay (ELISA) technique as contained in Biochek assay kits was used to test for the effect of both extracts on the serum level of estradiol, progesterone, follicle stimulating hormone, luteinizing hormones and prolactin.

\subsection{Statistical Analysis}

Statistical Analysis of Variance (ANOVA) was done using the Statistical package for Social Sciences (SPSS) version 22.0 and results expressed in tables as mean \pm standard error of the mean SEM, respectively. The significance level was accepted at $p<0.05$.

\section{RESULTS}

Table 1. The effect of administration of $S$. jollyanum extracts on estradiol levels

\begin{tabular}{llll}
\hline $\begin{array}{l}\text { Sample } \\
\text { groups }\end{array}$ & $\begin{array}{l}\text { Dose } \\
(\mathbf{m g} / \mathbf{k g})\end{array}$ & $\begin{array}{l}\text { No. of } \\
\text { rats }\end{array}$ & $\begin{array}{l}\text { Estradiol } \\
\mathbf{p g} / \mathbf{m L}\end{array}$ \\
\hline Control & - & 4 & $8.52 \pm 0.18$ \\
MeOH & 400 & 4 & $8.70 \pm 0.40$ \\
Aqueous & 400 & 4 & $7.97 \pm 0.35$ \\
\hline From the table above, there is no significant $(p>0.05)$ \\
difference in the treated groups when compared against \\
\multicolumn{4}{c}{ the control group }
\end{tabular}

Table 2. The effect of administration of $S$. jollyanum extracts on progesterone levels

\begin{tabular}{llll}
\hline $\begin{array}{l}\text { Sample } \\
\text { groups }\end{array}$ & $\begin{array}{l}\text { Dose } \\
(\mathbf{m g} / \mathbf{k g})\end{array}$ & $\begin{array}{l}\text { No. of } \\
\text { rats }\end{array}$ & $\begin{array}{l}\text { Progesterone } \\
\mathbf{p g} / \mathbf{m L}\end{array}$ \\
\hline Control & - & 4 & $10.69 \pm 0.12$ \\
MeOH & 400 & 4 & $9.33 \pm 0.27$ \\
Aqueous & 400 & 4 & $9.21 \pm 0.19$ \\
\hline \multicolumn{3}{c}{ From the table above, there is no significant $(p>0.05)$} \\
difference in the treated groups when compared against \\
\multicolumn{4}{c}{ the control group }
\end{tabular}

Table 3. The effect of administration of $S$. jollyanum Extracts on Follicle Stimulating Hormone (FSH) Levels

\begin{tabular}{llll}
\hline $\begin{array}{l}\text { Sample } \\
\text { groups }\end{array}$ & $\begin{array}{l}\text { Dose } \\
(\mathbf{m g} / \mathbf{k g})\end{array}$ & $\begin{array}{l}\text { No. of } \\
\text { rats }\end{array}$ & $\begin{array}{l}\text { FSH } \\
\text { miu/L }\end{array}$ \\
\hline Control & - & 4 & $9.29 \pm 1.59$ \\
MeOH & 400 & 4 & $6.71 \pm 1.06^{*}$ \\
Aqueous & 400 & 4 & $5.00 \pm 0.43^{*}$ \\
\hline \multicolumn{4}{c}{ The figures marked with asterisk show significant } \\
(p<0.05) difference when the groups are compared \\
\multicolumn{4}{c}{ against the control group }
\end{tabular}


Table 4. The effect of administration of $S$. jollyanum extracts on luteinizing hormone (LH) levels

\begin{tabular}{llll}
\hline $\begin{array}{l}\text { Sample } \\
\text { groups }\end{array}$ & $\begin{array}{l}\text { Dose } \\
(\mathbf{m g} / \mathbf{k g})\end{array}$ & $\begin{array}{l}\text { No. of } \\
\text { rats }\end{array}$ & LH miu/L \\
\hline Control & - & 4 & $4.29 \pm 0.48$ \\
MeOH & 400 & 4 & $3.20 \pm 0.41$ \\
Aqueous & 400 & 4 & $2.65 \pm 0.25^{*}$ \\
\hline \multicolumn{3}{c}{ The figure marked with asterisk shows significant } \\
(p<0.05) difference when the group is compared against \\
\multicolumn{4}{c}{ the control group }
\end{tabular}

Table 5. The effect of administration of $S$. jollyanum extracts on prolactin levels

\begin{tabular}{llll}
\hline $\begin{array}{l}\text { Sample } \\
\text { groups }\end{array}$ & $\begin{array}{l}\text { Dose } \\
(\mathbf{m g} / \mathbf{k g})\end{array}$ & $\begin{array}{l}\text { No. of } \\
\text { rats }\end{array}$ & $\begin{array}{l}\text { Prolactin } \\
\mathbf{n g} / \mathbf{m L}\end{array}$ \\
\hline Control & - & 4 & $38.48 \pm 1.55$ \\
MeOH & 400 & 4 & $39.70 \pm 1.66$ \\
Aqueous & 400 & 4 & $33.57 \pm 0.77^{*}$ \\
\hline \multicolumn{3}{c}{ The figure marked with asterisk shows significant } \\
(p<0.05) difference when the group is compared against \\
\multicolumn{4}{c}{ the control group. }
\end{tabular}

Table 6. The effect of administration of $S$. jollyanum extracts on testosterone levels

\begin{tabular}{llll}
\hline $\begin{array}{l}\text { Sample } \\
\text { groups }\end{array}$ & $\begin{array}{l}\text { Dose } \\
\text { (mg/kg) }\end{array}$ & $\begin{array}{l}\text { No. of } \\
\text { rats }\end{array}$ & $\begin{array}{l}\text { Testosterone } \\
\mathbf{n g} / \mathbf{m L}\end{array}$ \\
\hline Control & - & 4 & $10.51 \pm 1.61$ \\
MeOH & 400 & 4 & $9.49 \pm 0.81$ \\
Aqueous & 400 & 4 & $6.99 \pm 0.70^{*}$ \\
\hline \multicolumn{3}{c}{ The figure marked with asterisk shows significant } \\
(p<0.05) difference when the group is compared against \\
\multicolumn{4}{c}{ the control group }
\end{tabular}

Table 7. The effect of administration of $S$. jollyanum extracts on follicle stimulating hormone (FSH) levels

\begin{tabular}{llll}
\hline $\begin{array}{l}\text { Sample } \\
\text { groups }\end{array}$ & $\begin{array}{l}\text { Dose } \\
(\mathbf{m g} / \mathbf{k g})\end{array}$ & $\begin{array}{l}\text { No. of } \\
\text { rats }\end{array}$ & $\begin{array}{l}\text { FSH } \\
\text { miu/L }\end{array}$ \\
\hline Control & - & 4 & $9.58 \pm 0.60$ \\
MeOH & 400 & 4 & $5.55 \pm 0.62^{*}$ \\
Aqueous & 400 & 4 & $5.27 \pm 0.26^{*}$ \\
\hline \multicolumn{3}{c}{ The figure } & marked with asterisk shows significant \\
$(p<0.05)$ difference when the groups are compared \\
against the control group
\end{tabular}

Table 8. The effect of administration of $S$. jollyanum extracts on luteinizing hormone (LH) levels

\begin{tabular}{llll}
\hline $\begin{array}{l}\text { Sample } \\
\text { groups }\end{array}$ & $\begin{array}{l}\text { Dose } \\
(\mathbf{m g} / \mathbf{k g})\end{array}$ & $\begin{array}{l}\text { No. of } \\
\text { rats }\end{array}$ & $\begin{array}{l}\text { LH } \\
\text { miu/L }\end{array}$ \\
\hline Control & - & 4 & $4.92 \pm 0.66$ \\
MeOH & 400 & 4 & $3.08 \pm 0.38$ \\
Aqueous & 400 & 4 & $3.09 \pm 0.25$ \\
\hline From the table above, there is no significant $(p>0.05)$ \\
difference in the treated groups when compared against \\
the control group
\end{tabular}

\section{DISCUSSION AND CONCLUSION}

The use of herbs in the management of ailment has been a regular practice in Africa with considerable therapeutic successes [19]. Sphenocentrum jollyanum has been used traditionally for the treatment of various diseases. Result shown in Table 1 indicates a nonsignificant $(p>0.05)$ decrease in estradiol level of the aqueous groups when compared to the control. Estradiol is directly responsible for the growth and development of reproductive organs through its stimulatory effect on proliferation of the granulose cell during follicular development [20]. The reduction in the serum concentration of estradiol observed in the treated group may be attributed to decreased aromatase activity or substrate supplementation during estrogen synthesis [6]. Consequently, such decrease in estradiol levels may disrupt ovulation, preparation of reproductive tract for zygote implantation and the subsequent maintenance of pregnancy state [20]. Plants rich in estrogenic properties can directly influence the pituitary action by peripheral modulation of follicle stimulating hormone and luteinizing hormone decreasing the secretion of these hormones and blocking ovulation [1]. A non-significant $(p>0.05)$ decrease was observed in progesterone level of rats administered both methanol and aqueous extracts when compared to the control. Progesterone is essential for the implantation and maintenance of early human pregnancy and is produced by the granulose-lutein cells of the corpus luteum during the luteal phase of the menstrual cycle. This phase of the menstrual cycle is dominated by progesterone [21] and acts in a local manner to mediate ovulation and luteinisation [22]. Increase in progesterone levels and in progesterone receptors expression within 12 hours of the ovulatory stimulus in the macaque follicle supports its critical early role in ovulation and luteinisation [23]. The reduction in progesterone levels (though not significant) obtained in this study suggests that the extract has the ability to inhibit progesterone secretion which may affect its role in ovulation and luteinisation. Follicle stimulating hormone is a naturally occurring hormone, a member of the glycoprotein hormone family that has essential and central role in reproduction. It is essential for gonadal development and maturation of puberty as well as gamete production during fertile phase of life [24]. It stimulates growth and maturation of ovarian follicle by acting directly on receptors on the granulose cells. A fluctuating baseline follicle stimulating hormone level is indicative of 
compromised ovarian function and is further enhanced, if measurement of follicle stimulating hormone is combined with serum estradiol and inhibin [25]. The principle function of follicle stimulating hormone is to stimulate gametogenesis, follicular development in females and spermatogenesis in male [26]. The decrease in the serum levels of follicle stimulating hormone in rats administered both extracts is likely as a result of the influence of the extracts on the anterior pituitary or the hypothalamus. In Table 5, a non-significant $(p>0.05)$ and significant $(p<0.05)$ decrease in luteinizing hormone is observed in the methanolic and aqueous extracts respectively when compared to the control. Studies have shown that luteinizing hormone release surges at the pre-estrous stage and are responsible for ovulation $[27,28]$. Any substance capable of inhibiting this release could provoke disruption of ovulation by decreasing the number of mature follicles or induce an estrous cycle disruption at rest [29]. The reduction in level of serum luteinizing hormone indicates the inhibitory effect of the extract on the disruption of ovulation which may result in impairment of oestrous cycle, hampering conception and normal reproduction in females. The result shown in table 5 of this study indicates that aqueous extract of Sphenocentrum jollyanum significantly $(p<0.05)$ decreased serum prolactin in female while the methanolic extract shows a non-significant $(p>0.05)$ increase compared to the control. Prolactin helps to initiate breast development by inducing labulo-alveolar growth of the mammary gland. It also stimulates lactogenesis. Dopamine serves as the major inhibiting factor on prolactin secretion [30]. Prolactin increases during pregnancy causing the mammary gland to enlarge in preparation for breastfeeding and ready to secrete colostrums closely after delivery. Elevated prolactin levels are seen during gestation and lactation and is associated with anovulation which may directly or indirectly cause infertility. The reduction in this hormone indicates the inhibitory effect of the extract on prolactin which shows that the extract has other mechanism of inhibiting pregnancy other than by increasing prolactin since prolactin directly increases estradiol and progesterone and inhibits follicle stimulating hormone and luteinizig hormone [31].

In males, follicle stimulating hormone ( $\mathrm{FSH})$, luteinizing hormone $(\mathrm{LH})$ and testosterone are essential for normal functioning of the testes and healthy spermatogenesis [32,33]. The results of this study showed that the oral administration of aqueous extract of Sphenocentrum jollyanum significantly $(p<0.05)$ reduced the serum levels of testosterone and follicle stimulating hormone and non-significantly $(p>0.05)$ decreased luteinizing hormone. The methanol extract showed a significant $(p<0.05)$ decrease in the follicle stimulating hormone and a non-significant $(p>0.05)$ decrease in testosterone and luteinizing hormone. The decrease in the serum level of luteinizing hormone is in agreement with the study of Owiredu et al. [34] who also reported that ethanol extract of the plant caused a dose dependent decrease. Studies carried out by Dewick, [35] Francis et al. [36] and Robert and Wink, [37], reported that some phytochemicals like saponin and alkaloid exerts toxic effects on reproductive hormones. Alkaloids have been also shown to reduce serum concentration of $\mathrm{LH}$ and FSH [38]. Root extract of Sphenocentrum jollyanum is rich in alkaloids [39]. Thus, the presence of alkaloid may be responsible for the alteration in the hormone level. The reduction of serum level of testosterone could probably be due to the decrease in serum levels of $\mathrm{LH}$ observed in this study. Luteinizing hormone stimulates secretion of sex steroids from the gonads [1]. Any substance capable of inhibiting this release could provoke disruption of spermatogenesis. The reduction in serum level of lutenizing hormone suggests the inhibitory effect of the extract on the release of lutenizing hormone which may trigger disruption of spermatogenesis. This may result in impairment of oestrous cycle, hamper conception and reproduction in females and normal sperm production in males. Leydig cells in the testis stimulates secretion of testosterone by stimulatory effect of luteinizing hormone [40,41] and follicle stimulating hormone induces spermatogenesis. The mechanism of action of how LH stimulates leydig to secrete testosterone occurs via activation of cAMP second messenger system, thus increases in intracellular cAMP then activates protein kinase $A$ which results in phosphorylation of specific protein producing an increase in steroid production [42]. According to Francis et al. [36] saponin was found to directly inhibit the genes responsible for steroidogenesis, and also Yu et al. [43] had reported that saponins lower serum androgens and $17 \beta$-estradiol. Since saponin was detected in the plant in previous studies by Woode et al. [44] and Ajayi et al. [45], this could also be a cause of reduction of testosterone. Furthermore, aqueous extract of Sphenocentrum jollyanum has no significant effect on the testicular size when compared to the control in all parameters (left, right and pair) 
while the methanol extract affected only the pair when compared to the control.

\section{ETHICAL APPROVAL}

All authors hereby declare that "Principles of laboratory animal care" (NIH publication No. 8523 , revised 1985) were followed.

As per international standard or university standard written ethical approval has been collected and preserved by the authors.

\section{COMPETING INTERESTS}

Authors have declared that no competing interests exist.

\section{REFERENCES}

1. Brinker F. Inhibition of endocrine function by botanical agents, antigonadotropic activity. Br J Phytother. 1997;4:123-45.

2. Hess RA, Renato de Franca $L$. Spermatogenesis and cycle of the seminiferous epithelium. Advances in Experimental Medicine and Biology. 2008; 636:1-15.

3. Hameed S, Jayasena CN, Dhillo WS. Kisspeptin and fertility. Journal of Endocrinology. 2011;208:97-105.

4. Suresh Ramaswamy and Gerhard F Weinbauer. A review on endocrine control of spermatogenesis: Role of $\mathrm{FSH}$ and $\mathrm{LH} /$ testosterone. Spermatogenesis. 2014; 4(2):1-15.

5. Peiris Dinithi $C$, Jayatilleka $H$, Dhanushka $T$. Evaluation of aqueous leaf extract of Cardiospermum halicacabum (L.) on fertility of male rats. Biomed Central International Research; 2015.

6. Edeoga HO, Okwu DE, Mbaebie BO. Phytochemical constituents of some nigerian medicinal plants. Afr. J. Biotechnol. 2005;4(7):685-688.

7. Vishwakarma AP, Vishwe A, Sahu $P$, Chaurasiya A. Magical remedies of Terminalia arjuna (ROXB.). International Journal of Pharmaceutical Archive. 2013; 2:189-201.

8. Folu M, Dania O, Oyomoare L, Erugun, Merilyn U. Scientific research and essay. 2009;4(3):120-130.

9. Muhammad D, Muhammad A. Antifertility activity of medicinal plants. Journal of the
Chinese Medical Association. 2014;78: 382-388.

10. Khojasteh SMB, Khameneh RJ, Houresfsnd M, Yaldagard E. A review on medicinal plants used for improvement of spermatogenesis. Biol Med (Aligarh). 2016;8:292.

DOI: $10.4172 / 0974-8369.1000292$

11. Rahaman Onike, A review of medicinal values of Sphenocentrum jollyanum (akerejupon) in African Alternative Medicine; 2010.

Available:http://searchwarp.com/swa61671 1-A-Review-of-Medicinal-Values-of-

Sphenocentrum-Jollyanum-Akerejupon-InAfrican.htm

12. Alese $\mathrm{MO}$, Adewole SO, ljomone $\mathrm{MO}$, Ajayi SA, Omonisi A. Histological studies of pancreatic $\beta$-cells of treated with Sphenocentrum jollyanum. JPSI. 2013; 2(2):8-12.

13. Mbaka GO, Adeyemi OO, Noroha CC, Okanlawon OA, Osinubi A. Effects of aqueous root extract of Sphenocentrum jollyanum on blood glucose level of rabbits. J. Med. Plant. Res. 2009;3(11):870-874.

14. Abbiw DK. Useful plants of Ghana. Intermediate Technol Pub and Royal Botanic Gardens Kew; 1990.

15. Burkill HM. The useful plants of West Tropical Africa. Royal Botanical Gardens: Kew. 1985;1.

16. Oke JM, Hamburger MO. Screening of some Nigeria medicinal plants for antioxidant acitivity using 2,2-diphenylpicryl-hydrazyl radical. Afr. J. Biomed. Res. 2002;5(1-2):77-79.

17. Olorunnisola OS, Afolayan AJ. In vivo antimalaria activity of methanolic leaf and root extracts of Sphenocentrum jollyanum Pierre. African Journal of Pharmacy and Pharmacology. 2011;5(14):1669-1673.

18. Egunyomi A, Fasola TR, Oladunjoye $O$. Charring medicinal plants: A traditional method of preparing phytomedicines in South-western Nigeria. Ethnobotany Journal. 2005;3:261-265.

19. Egba SI, Omodamiro OD, Obike JC, Ali ES. Influence on some female fertility hormonal response in wistar albino rats: Possible contraceptive role for methanol leaf extract of Ocimum gratissimum? J. Chem. Pharm. Res. 2015;7(5):889-898.

20. Hsia SM, Yeh YH, Wang PS, Chiang W. Effects of polybrominated diphenyl ethers 
on steroidogenesis in rat Leydig cells. Exptal Bio Med. 2007;232:118-119.

21. Suzuki T, Sasano H, Kimura N, Tamura M, Fukaya $T$, Yajima A, Nagura $H$. Immunohistochemical distribution of progesterone, androgen and oestrogen receptors in the human ovary during the menstrual cycle: Relationship to expression of steroidogenic enzymes. Hum. Eprod. 1994;9:1589-95.

22. Pratap K, Navneet $M$. Hormones in pregnancy. Niger Med J. 2012;53(4):179183.

23. Muasher SJ, Oehninger S, Simonetti S, Matta J, Ellis LM, Liu HC, Jones GS, Rosenwaks Z. The value of basal and/or stimulated serum gonadotropin levels in prediction of stimulation response and in vitro fertilisation outcome. Fertil Steril. 1988;50:298-307.

24. Simoni M, Nieschlag E. FSH in therapy: Physiological basis, new preparations and clinical use. Reprod Med Rev. 1995;4:163177.

25. Litwack G, Schmidt RS. Biochemistry of hormone II: Polypeptide hormones. In: Delvin T. M. (ed) Textbook of Biochemistry with Clinical Correlation, 5th ed. John, New York: John Wiley and Sons Inc. 905-958.

26. Andrea DM, Ram S, Lucia M, Gian MF, Anne G, Marianne L, Paolo S. Impairing Follicle-Stimulating Hormone (FSH) signalling in vivo: Targeted disruption of the $\mathrm{FSH}$ receptor leads to aberrant gametogenesis and hormonal imbalance. Proc Natl Acad Sci USA. 1998;95(23): 13612-13617.

27. Anker JJ, Carroll ME. Females are more vulnerable to drug abuse than males: Evidence from preclinical studies and the role of ovarian hormone. Curr Top Behav Neurosci. 2011;8:73-96.

28. Gallo RV. Pulsatile LH release during the ovulatory LH surge onproestrus in the rat. Bio Reprod. 1981;24:100-104.

29. Gonzales GF, Rubio S, Chung A, Gasco $M$, Villegas L. Effect of alcoholic extract of Lepidium meyenii (Maca) on testicular function in male rats. Asia Journal Androl. 2003;5:349-52.

30. Dias JA, Campo B, Weaven BA, Watts J, Kluetzman K, Thomas RM, Bonnet B, Mutel V, Poli SM. Inhibition of follicle stimulating hormone-induced pre-ovulatory follicles in rats treated with a non-steroidal negative allosteric modulator of follicle stimulating hormone receptor. Biol Reprod. 2014;90(1):19.

31. David RG. Sixty years of endocrinology: The hypothalamo-prolactin axis. J. Endocrinol. 2015;226(2):T101-T122.

32. Dhanushka T, Peiris Dinithi C. Low doses of Chlorpyrifos interfered with spermatogenesis of male wistar rats through reduction of sex hormones. Journal of Pollution Research; 2017.

33. Odunole OO, Vydra N, Wood NEM, Samanta L, Owen L, Keevil B, Donaldson M, Naresh K, Huhtaniemi IT. Overlapping dose responses of spermatogenic and extragonadal testosterone actions jeopardize the principle of hormonal male contraception. FASEB J. 2014;28(6):25662576.

34. Dewick PM. Medicinal natural products: A biosynthetic approach. 2nd Edn., John Wiley and Sons, Chichester, UK; 2002.

35. Francis G, Kerem Z, Harinder P, Makkar $\mathrm{S}$, Becker $\mathrm{K}$. The biological action of saponins in animal systems: A review. British Journal of Nutrition. 2000;88:587605.

36. Robert MF, Wink M. Alkaloids; Biochemistry, ecology and medicinal applications. Plenum Press, New York; 1998.

37. Bianco F, Basini G, Grasselli F. The plant alkaloid Sanguinarine affects swine granulosa cell activity. Reproduction Toxicology. 2006;21:335-340.

38. Adebayo EM. Effects of oral administration of a decoction on serum levels of leuteinizing hormone, follicle stimulating hormone, progesterone and estradiol in female Dutch-white rabbits. Research Journal of Medicinal Plants. 2015;9:141145.

39. Wood JW. Oxford reviews of reproductive biology. New York: Oxford University Press; 1989.

40. Weinbauer GF, Luetjens CM, Simoni M, Nieschlag E. Physiology of testicular function. Andrology. 2010;24(5):765-774.

41. McClure RD. Endocrinology of male infertility. Andrology; 2005.

Available:http://www.springer.com/978-158829-318-3

42. Yu WJ, Lee BJ, Nam SY, Yang DC, Yun YW. Biology and Pharmaceutical Bulletin. 2003;26(11):1574-1580.

43. Woode E, Amidu N, Owiredu WK, BoakyeGyasi E, Ansah C, Duwiejua M. 
Anxiogenic-like effects of a root extract of Sphenocentrum jollyanum Pierre in Murine behavioural models. Journal of Pharmacology and Toxicology. 2009;4:91106.

44. Ajayi A, Olusola O. Phytochemical analysis and mineral element composition of ten medicinal plant seeds from South-west Nigeria. New York Science Journal. 2013;6(9):1-7.

45. Simoni M, Nieschlag E. FSH in therapy: Physiological basis, new preparations and clinical use. Reprod Med Rev. 1995;4:163177.

(c) 2017 Egba et al.; This is an Open Access article distributed under the terms of the Creative Commons Attribution License (http://creativecommons.org/licenses/by/4.0), which permits unrestricted use, distribution, and reproduction in any medium, provided the original work is properly cited. 